\title{
Quantifying forest structural diversity based on large-scale inventory data: a new approach to support biodiversity monitoring
}

\author{
Felix Storch $^{1 *}$ D, Carsten F. Dormann ${ }^{2}$ and Jürgen Bauhus ${ }^{1}$
}

\begin{abstract}
Background: The importance of structurally diverse forests for the conservation of biodiversity and provision of a wide range of ecosystem services has been widely recognised. However, tools to quantify structural diversity of forests in an objective and quantitative way across many forest types and sites are still needed, for example to support biodiversity monitoring. The existing approaches to quantify forest structural diversity are based on small geographical regions or single forest types, typically using only small data sets.

Results: Here we developed an index of structural diversity based on National Forest Inventory (NFI) data of BadenWürttemberg, Germany, a state with 1.3 million ha of diverse forest types in different ownerships. Based on a literature review, 11 aspects of structural diversity were identified a priori as crucially important to describe structural diversity. An initial comprehensive list of 52 variables derived from National Forest Inventory (NFI) data related to structural diversity was reduced by applying five selection criteria to arrive at one variable for each aspect of structural diversity. These variables comprise 1) quadratic mean diameter at breast height (DBH), 2) standard deviation of $\mathrm{DBH}, 3$ ) standard deviation of stand height, 4) number of decay classes, 5) bark-diversity index, 6) trees with $\mathrm{DBH} \geq 40 \mathrm{~cm}$, 7) diversity of flowering and fructification, 8) average mean diameter of downed deadwood, 9) mean DBH of standing deadwood, 10) tree species richness and 11) tree species richness in the regeneration layer. These variables were combined into a simple, additive index to quantify the level of structural diversity, which assumes values between 0 and 1 . We applied this index in an exemplary way to broad forest categories and ownerships to assess its feasibility to analyse structural diversity in large-scale forest inventories.
\end{abstract}

Conclusions: The forest structure index presented here can be derived in a similar way from standard inventory variables for most other large-scale forest inventories to provide important information about biodiversity relevant forest conditions and thus provide an evidence-base for forest management and planning as well as reporting.

Keywords: Stand structure, Structural diversity, Structural diversity index, Large-scale forest inventory, Angle count sampling

\footnotetext{
* Correspondence: felix.storch@waldbau.uni-freiburg.de

${ }^{1}$ Chair of Silviculture, Tennenbacherstr. 4, University of Freiburg, D-79085

Freiburg, Germany

Full list of author information is available at the end of the article
} 


\section{Background}

\section{The importance of forest structural elements for} biodiversity monitoring

Structurally diverse forests are important to maintain species-rich communities (Simpson 1949; Brunialti et al. 2010; Taboada et al. 2010). MacArthur and MacArthur (1961) showed for example, that diversity of birds can be stronger influenced by vertical heterogeneity of forest stands than by composition of tree species. A higher diversity of bark characteristics (shapes and expressions) can lead to higher species diversity by provision of different microhabitats (Recher 1991; Woinarski et al. 1997; Michel et al. 2011). Lassauce et al. (2011) found that diversity of saproxylic organisms in boreal forests is strongly correlated with volume and decay classes of deadwood and Bouget et al. (2013) recommended the diversification of deadwood (types of deadwood, diameter and length, decay classes, etc.) as a management tool for saproxylic beetles in deciduous forests.

Over the last decades, forest management approaches such as 'close-to-nature forestry' or 'retention forestry' have been recommended to improve habitat provision through an increase in quantities of structural elements such as deadwood and large old trees (Gustafsson et al. 2012; Bauhus et al. 2013). For practical implementation, this means extending rotation periods, retaining trees with microhabitat features, increasing deadwood volume and even creating standing dead trees and high stumps artificially (e.g. Ranius et al. 2005; Abrahamsson and Lindbladh 2006; Bauhus et al. 2009). While there is a reasonably good research foundation for these measures, there is only scant documentation about their effectiveness in routine forestry.

Yet in many jurisdictions, forest owners, in particular public forest authorities, are requested to monitor biodiversity and report on their management efforts to maintain or improve biodiversity. There is, as yet, no established or accepted monitoring approach for different types of ecosystems (Pielou 1975; Noss 1990). In addition, biodiversity is extremely difficult and very expensive to monitor (Lindenmayer and Franklin 2002; Gardner 2010). This is caused by a range of factors including species-specific characteristics like large home-ranges or seasonal appearances, even when the focus is 'only' on species richness or even only on endangered species. The approach of using indicator (key) species as a surrogate for biodiversity of forests has not been widely successful because of a lack of consistent correlations between the indicator species and the occurrence or abundance of other species (Van Den Meersschaut and Vandekerkhove 2000; Margules et al. 2002; Duelli and Obrist 2003). For those reasons, comprehensive approaches to monitor forest biodiversity comprising many different taxa have so far not been implemented in regular forest inventories.
In the context of forests, the main influence of management on biodiversity is through changes in forest structure and composition (Lindenmayer et al. 2000; Raison et al. 2001; Kuuluvainen 2009), where structure and composition are commonly deliberately manipulated to achieve certain ecosystem functions and services (Plieninger et al. 2010; Bauhus and Pyttel 2015). Thus it appears logical to monitor changes in these important determinants of biodiversity in the absence of direct data on forest species and their populations and genetic variation (Taboada et al. 2010). The monitoring of biodiversity relevant aspects of forest structure and composition may be integrated into standard forest inventories at little additional cost when compared to separate approaches for biodiversity monitoring (Corona 2016).

\section{Existing indices of forest structural diversity}

Several indices estimating structural diversity of forests have been described in the literature. Some focus on specific structural elements such as deadwood (Larsson 2001) or have been developed to assess specific habitat attributes of different species or species groups (e.g. 'Structural Complexity Index' for small mammals (Barnett et al. 1978) or 'Habitat Complexity Score' for assessment of bird habitats (Watson et al. 2001)). Others have been developed for particular geographical regions and focus mainly on one tree species or stand type ('Structural Heterogeneity Index' (Sabatini et al. 2015)). Indices such as the 'Old-Growth Index' (Acker et al. 1998) are related to structural diversity of old-growth stands, assuming the highest level of diversity to be found there. The 'Austrian Forest Biodiversity Index' is based on a relatively subjective set of variables derived from Austrian National Forest Inventory (NFI)-data (Geburek et al. 2010).

A comprehensive, quantitative index of structural diversity was developed by McElhinny et al. (2006) using a reproducible approach underlined by statistical analysis. In their approach, a comprehensive list of candidate variables was reduced to those that capture the variability of the different structural aspects best through Principal Component Analysis. This approach was modified and applied in our analysis to develop an index of structural diversity.

In general terms, structural diversity may be described by many different variables, or these may be combined into a single index value (e.g. McElhinny et al. 2006) as is also the case for other environmental indicators and indices (Niemeijer and de Groot 2008). One advantage of using a set of variables is the more detailed information about individual structural elements and their changes over inventory periods. This more detailed information may be required for the monitoring of certain aspects of structural diversity that are related to ecosystem functioning or habitat quality of particular taxonomic groups. This 
monitoring-oriented focus on individual aspects of structural diversity is particularly relevant for multipurpose forest management and planning (e.g. Corona 2016). The disadvantage of this approach is that it is less suitable for reporting purposes, especially for non-expert audiences. An aggregation of structural variables into a single index value facilitates reporting levels of structural diversity and their development over time in broad terms to a general audience including non-governmental organisations and decision makers. In that sense, such an aggregated index of forest structural diversity is similar to a 'state indicator' of the "pressure, state, response" concept of environmental indicators proposed by the OECD (2003). Here we combined these two approaches. On the one side, we identified individual structural variables that may be related to specific aspects of forest biodiversity and that may respond differently to forest management. On the other side, we combined these individual variables into a single number for an index of structural diversity to facilitate communication of changes in forest structure at a high level of information aggregation, for example to facilitate policy processes and decision making.

\section{Large-scale inventories to support biodiversity monitoring}

So far, large-scale inventories have been rarely used to determine the level of structural diversity (Kändler 2006; Polley 2010). However, valuable information about diversity of forests can be obtained as a 'byproduct' of existing inventory data and therefore at low costs (Corona et al. 2003; Corona et al. 2011). One advantage of such an inventory is the wide range of sampled forest attributes. Yet these types of NFI were originally not developed to capture forest structure but the main reason for the development and implementation was to analyse the development of forest growing stock and the available amounts of different types of forest products. However, the information demand gradually increased and hence additional variables with high relevance for the quantification of forest structure were included. For example, in the $\mathrm{NFI}_{2002}$, variables related to biodiversity and carbon storage such as deadwood (dimensions, decay classes, types of deadwood) or regeneration were added. 'Hollow trees', as well as other habitat-tree characteristics (very old trees or crown deadwood) were added in the $\mathrm{NFI}_{2012}$.

The large area covered as well as the number of sample plots used in the inventories allows quantification of structural diversity for different forest types. An overview of strengths and weaknesses of the applied large-scale inventory for the assessment of structural diversity is provided in Table 1 .

Based on NFI data, indices of forests structural diversity may be developed. This could permit the quantification of levels of structural diversity in different forest types, as well as its changes over inventory periods (e.g. 10 years). Subsequently these changes may be related to other inventory information such as harvesting intensity. Indices that are based on standard inventory variables may be transferred to other large-scale forest inventories and thus facilitate assessments of structural diversity over large areas within or across jurisdictions (Chirici et al. 2011; Corona et al. 2011).

Table 1 Strengths and weaknesses of large-scale forest inventories such as the German NFI to assess surrogates for biodiversity based on forest structural diversity

\begin{tabular}{|c|c|}
\hline Strengths & Weaknesses \\
\hline $\begin{array}{l}\text { Large number of inventory plots for different strata such as } \\
\text { jurisdictions or biogeographical regions and broad forest types }\end{array}$ & $\begin{array}{l}\text { Sampling based on angle count method; only a selection of trees are sampled, which } \\
\text { leads to a loss of information at the plot-level (probability proportional to size) }\end{array}$ \\
\hline Approach applicable to NFIs of other countries & $\begin{array}{l}\text { The large-scale design ( } 2 \mathrm{~km} \times 2 \mathrm{~km} \text { grid) does not capture effectively small areas } \\
\text { like forest reserves }\end{array}$ \\
\hline $\begin{array}{l}\text { Adequate number of sampling plots per forest type available } \\
\text { (for main forest types, see Additional file } 5 \text { ) }\end{array}$ & $\begin{array}{l}\text { Biodiversity-relevant variables were originally not included in inventory-samplings; } \\
\text { increasing integration of biodiversity-relevant variables only in recent inventories } \\
\left(\mathrm{NFI}_{2002} \text { and } \mathrm{NFI}_{2012}\right)\end{array}$ \\
\hline $\begin{array}{l}\text { Low costs for acquisition of data that are attached to or can be } \\
\text { derived from classical inventory variables }\end{array}$ & $\begin{array}{l}\text { No precise information about harvesting and other management activities at the } \\
\text { plot-level }\end{array}$ \\
\hline $\begin{array}{l}\text { Dynamic changes over inventory periods can be considered } \\
\text { (ongoing process) }\end{array}$ & $\begin{array}{l}\text { Changes in sampled variables and sampling thresholds between NFIs (e.g. threshold- } \\
\text { value for the minimal diameter for downed deadwood or the presence of hollows) }\end{array}$ \\
\hline $\begin{array}{l}\text { Same plots are re-sampled } \\
\rightarrow \text { Analysis on changes of structural elements and development } \\
\text { of individual trees (over periods of } 10 \text { years) }\end{array}$ & $\begin{array}{l}\text { While broad forest types can be analysed, local (regional) aspects may not be } \\
\text { sufficiently well represented }\end{array}$ \\
\hline \multirow[t]{2}{*}{$\begin{array}{l}\text { A large number and variety of structural variables can be derived } \\
\text { from inventory data }\end{array}$} & $\begin{array}{l}\text { Owing to the sampling method and related small radius of sampling circles, plot } \\
\text { measures are not representative of the stand in which they were collected; } \\
\text { therefore extrapolation to hectare values is problematic }\end{array}$ \\
\hline & $\begin{array}{l}\text { Some important variables of forest structure are not quantified directly. They can } \\
\text { only be addresses through surrogates (e.g. the occurrence of large living trees as } \\
\text { surrogate for habitat-tree characteristics) }\end{array}$ \\
\hline
\end{tabular}




\section{Study aims}

The main goal of this study was to explore the potential of large-scale forest inventories to assess forest structural diversity and its development over time using an objective and quantitative way to support biodiversity monitoring (Table 1). Based on the successful development of an index of structural diversity, we present, in an exemplary form, information on the status and development of structural diversity in different forest types of Baden-Württemberg, Germany.

\section{Methods}

Data of two National Forest Inventories of Germany for the state of Baden-Württemberg $\left(\mathrm{NFI}_{2002}\right.$ and $\left.\mathrm{NFI}_{2012}\right)$ were used for this study. The inventory design was based on a systematic sampling grid of $2 \mathrm{~km} \times 2 \mathrm{~km}$ for the state of Baden-Württemberg, which has a denser grid than most other states with $4 \mathrm{~km} \times 4 \mathrm{~km}$. In the north-east corner of each grid intersection point, up to 4 permanent sampling plots (1-4) were marked invisibly (if located in forest areas) at a distance of $150 \mathrm{~m}$ to each other. In Baden-Württemberg, about 12.920 forest plots were sampled at both inventories and used in this analysis (Fig. 1).

At each sampling plot, a combination of sampling methods was used to collect forest stand attributes (Additional file 1). The complete sampling design and further information about the inventory can be found at https://www.bundeswaldinventur.de.

To construct an index of structural diversity of forests ('FSI' = Forest Structure Index), we adopted and improved the method developed by McElhinny et al. (2006). This approach consisted of 4 steps:

1) Defining aspects of structural diversity. Based on a literature review and the information derivable from NFI data, 11 aspects of structural diversity were identified to be represented in a comprehensive index.
2) Establishing a comprehensive list of structural variables derived from National Forest Inventory data (measured in both $\mathrm{NFI}_{2002}$ and $\mathrm{NFI}_{2012}$ ) that are related to the above aspects of structural diversity. Each variable belongs to one aspect of structural diversity (Table 2, see also Sabatini et al. 2015).

3) Reducing the number of variables to a core set of structural attributes by applying the following five selection criteria: a) distribution of data for the different variables should cover as much as possible the potential range of values and be as even as possible; unlike McElhinny et al. (2006), who used kurtosis as a criterion to assess the distribution of data for each variable, here the distribution was assessed visually. Testing the distribution of variables was mandatory because variables with wide spread and/or evenly distributed data are most suitable for this analysis. Variables with highly skewed data distributions or rare observations were not appropriate, because they would likely not be able to discriminate between different levels of structure across the plots; b) the variable functions as a surrogate for other variables of the same aspect c) continuous variables are better suited than categorical variables (aggregation in classes leads to a loss of information, enhanced by subjective class limits); d) all aspects of structural diversity must be included in the index (Table 2); e) the variable shall be a non-compound measure, excluding for example Shannon-like indices which amalgamate richness and abundance.

4) Combining core variables into a simple additive index, scored relatively to observed maxima in $\mathrm{NFI}_{2002}$.

The information provided by core variables had to be transferred and combined into a single index-score to express the overall level of structural diversity in forests and hence to allow the assessment of temporal changes

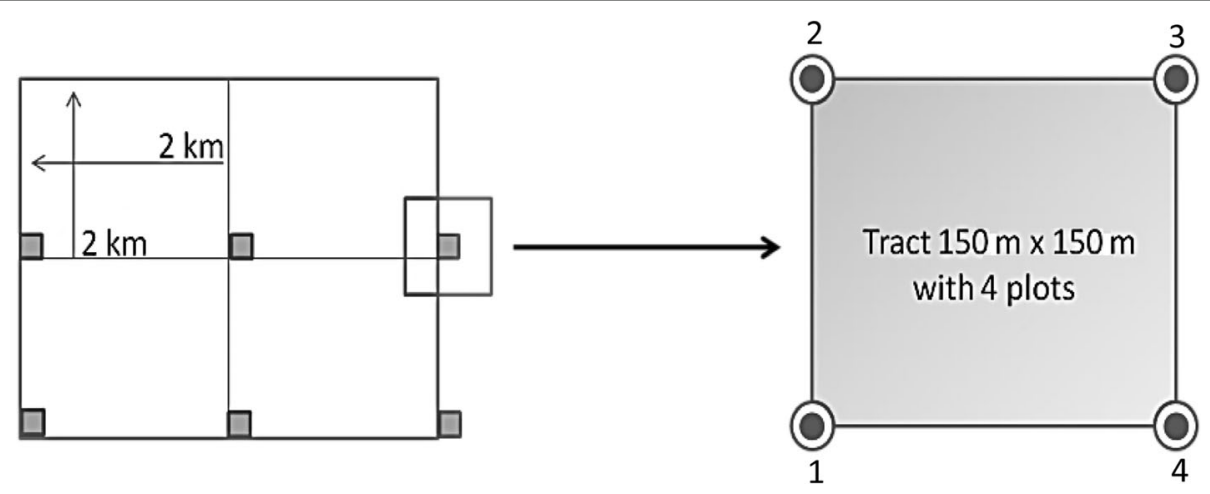

Fig. 1 Sampling grid of $\mathrm{NFI}_{2002}$ and $\mathrm{NFI}_{2012}$ in Baden-Württemberg, Germany 
Table 2 Aspects of structural diversity and references for publications, in which the ecological rationale for the relevance of the different aspects of structural diversity for forest biodiversity are provided; see also Sabatini et al. (2015). The right column refers to the number of variables that can be derived from the National Forest Inventory in relation to this aspect. The complete list of these 52 variables is provided in the Additional file 3. The aspects 'litter layer, 'microhabitats, 'tree spacing' and 'epiphytes and organisms on deadwood' could not be considered in this analysis because they were not sampled by the NFI. Some 'microhabitats' were only added to sampling during $\mathrm{NFI}_{2012}$, so they could not be taken into account for this work

\begin{tabular}{|c|c|c|c|}
\hline Aspect of structural diversity & Acronym & Authors & Number of variables \\
\hline Uneven-agedness & UA & Keeton (2006); Hatanaka et al. (2011) & 7 \\
\hline Growing stock & GS & Houghton (2005); Norris et al. (2012); Hoover et al. (2012) & 7 \\
\hline Compositional heterogeneity & $\mathrm{CH}$ & $\begin{array}{l}\text { Barbier et al. (2008); Barbier et al. (2009); Burrascano et al. (2011); } \\
\text { Hatanaka et al. (2011) }\end{array}$ & 5 \\
\hline Vertical heterogeneity & $\mathrm{VH}$ & Staudhammer and LeMay (2001); Hao et al. (2007); Burrascano et al. (2013) & 3 \\
\hline Large living trees & LLT & Nilsson et al. (2002); Brunialti et al. (2010); Persiani et al. (2010) & 3 \\
\hline Deadwood standing & DW st & Brunialti et al. (2010); Hatanaka et al. (2011) & 5 \\
\hline Deadwood downed & DW d & Castagneri et al. (2010); Lassauce et al. (2011); Zotti et al. (2013) & 8 \\
\hline Deadwood decay classes & DW DC & Burrascano et al. (2008); Lassauce et al. (2011); Lombardi et al. (2011) & 2 \\
\hline Bark diversity & $\mathrm{BD}$ & Bhadra et al. (2008); MacFarlane and Luo (2009); Michel et al. (2011) & 1 \\
\hline Diversity of flowering and fruiting trees & $\mathrm{FD}$ & Singh and Kushwaha (2005) & 1 \\
\hline Regeneration & REG & Hello (1985); Boyden et al. (2005); Müller et al. (2008) & 10 \\
\hline Litter layer & $\mathrm{LL}$ & $\begin{array}{l}\text { Barnett et al. (1978); Newsome and Catling (1979); Gilmore (1985) } \\
\text { (for habitats of birds); Watson et al. (2001) }\end{array}$ & 0 \\
\hline Microhabitats & $\mathrm{MH}$ & $\begin{array}{l}\text { Dueser and Shugart (1978); Winter and Möller (2008); } \\
\text { Michel et al. (2011); Bütler et al. (2013) }\end{array}$ & 0 \\
\hline Tree spacing & TS & $\begin{array}{l}\text { Spies and Franklin (1991); Pretzsch (1997); Acker et al. (1998); } \\
\text { Bachofen and Zingg (2001) }\end{array}$ & 0 \\
\hline $\begin{array}{l}\text { Epiphytes and organisms on deadwood } \\
\text { (lichen, mosses, fungi) }\end{array}$ & DW G & $\begin{array}{l}\text { Humphrey et al. (2002); Blaser et al. (2013); Dittrich et al. (2014); } \\
\text { Hoppe et al. (2016) }\end{array}$ & 0 \\
\hline
\end{tabular}

over a period of time (development) or comparisons among different forest types. If NFI-values were assumed to include extreme values (caused by the sampling method) or implausible measurements, ranges of possible minimum and maximum values for the respective variables were used, based on $\mathrm{NFI}_{2002}$ data or literature. All variables showing higher values than the threshold-value were reduced to the maximum score of 1 . Thereby, the loss of information was very small, because only few sampling plots were affected. An overview of the applied threshold-values is provided in Additional file 2.

The equation to calculate variables-scores:

$$
\text { Variable-Score }=\frac{\left(X-X_{\min }\right)}{\left(X_{\max }-X_{\min }\right)}
$$

$X$ was the measured variable-value at plot-level and $X_{\min }$ respectively $X_{\max }$ were the minimum and maximum values observed in $\mathrm{NFI}_{2002}$ data for each variable.

The sum of scores of the core variables divided by the number of variables included in this index yields a value between 0 and 1, where 0 indicates 'lowest level of structural diversity' and 1 'highest level of structural diversity'. Multiplying variables to calculate an index value, as was done for example in the index developed by Geburek et al. (2010), was regarded as unsuitable in our case because it assumes that structural diversity is depending on the presence of all structural elements captured by the variables (Burgman et al. 2001). If a single variable had a value of zero, the complete index would be zero. Rejecting those zero-values from index calculations would solve this problem but prevent a further comparison of indexscores, if these are based on different numbers of applied variables. Therefore, we decided to follow an additive way to construct this index as described above.

In theory, the individual variables of the index could receive a different weight according to their relevance for overall richness of habitats and associated species. Here, the index was calculated with unweighted variables because we had no prior information whether individual variables of forest structure were more or less important than others, e.g. for species richness within certain taxonomic groups. To test whether the assignment of different weightings to individual variables has a significant influence on the distribution of index values across inventory plots, a sensitivity analysis was performed, using for each variable random weightings between 0 and 2 , which were repeated 100,000 times.

Finally, sampling plots were aggregated to forest types by different stand attributes like dominant tree functional type 
(broadleaf or coniferous species), stand development phase, dominant tree species (beech, oak, spruce or pine), forest-ownership or number of canopy-layers. For these forest types, mean FSI-scores were calculated for both inventories and compared to each other, as well as among different types of forests. Thus, information was aggregated from the plot- to the forest-type level and a statement about the structural diversity as well as changes in structural diversity in forests representing large areas was possible.

Microsoft Access 2010 was used to calculate variables, derived from $\mathrm{NFI}_{2002}$ and $\mathrm{NFI}_{2012}$, describing structural diversity of forests. For further analysis, the statistic software $\mathrm{R}$ (Version 3.1.2) and its package beanplot was used for beanplots.

\section{The study area}

Almost 39\% or 1.371 million ha of the area of BadenWürttemberg (SW-Germany) is covered by forests. To develop an index for structural diversity, 13.106 inventory plots of $\mathrm{NFI}_{2002}$ were used. By excluding plots that a) were without merchantable timber at the time of $\mathrm{NFI}_{2002}, \mathrm{~b}$ ) experienced a change in land use (e.g. plot covered by forest at $\mathrm{NFI}_{2002}$ but converted into urban or agricultural land at $\mathrm{NFI}_{2012}$ ), and c) that were not accessible at both inventory dates, 12.918 plots or $98.6 \%$ of all sampled forest plots remained for this analysis.

\section{Results and discussion}

\section{Aspects of structural diversity}

In a first step, we identified through a broad literature review 11 aspects of structural diversity that should be included in a comprehensive index of forest structural diversity (FSI) (Table 2).

\section{Core variables of structural attributes}

After application of the above mentioned selection criteria, the following variables were identified as the most suitable to represent the corresponding aspect of structural diversity (Table 3). If reduction of variables resulted in more than one variable that was suitable to represent the aspect of structural diversity, a Principal Component Analysis (PCA) could be performed. To perform a PCA, distribution of variable-data must be approximately normal. In our study, this final step was not necessary because only one variable per aspect was considered as suitable for a further application in the index.

Even though some of these applied variables were closely correlated, we did not remove any of them for subsequent development of the index because they represented clearly different aspects of structural diversity. For example 'volume of trees $\geq 40 \mathrm{~cm}$ DBH' (describing the aspect of large living trees) and 'species richness of trees with $\mathrm{DBH} \geq 7$ cm' (describing compositional heterogeneity) were highly correlated. The correlations among different variables associated with a particular aspect of structural heterogeneity as well as correlations with other variables for the whole forest of Baden-Württemberg are listed in Additional file 4.

\section{Scaling of variables to derive index values}

Extreme values of variables (outliers), leading to scores higher than 1 were reduced to a score of 1 to maintain the data distribution unchanged and use the whole spectrum of data-variety for the analysis. The low values for downed deadwood, standing deadwood and number of decay classes (Fig. 3) can be explained by the distribution of data for these variables, respectively the large number of sampling plots without deadwood or different decay classes. In addition, the small sampling plot for deadwood applied in the NFI (radius of $5 \mathrm{~m}$ ), exacerbates this problem, because deadwood occurs often in a clumped distribution and is not equally distributed within forest stands, so the actual amounts of deadwood might not be recorded accurately.

\section{Scaling up from plot to forest type-level}

To aggregate information on structural diversity (FSIscore) from a plot- to a forest type-level, single plots were assigned to strata, here categories of forest types (related to NFI-classifications, e.g. ownership or number of canopy layers). It is important to work with larger forest types that are represented by an adequate number of sampling plots (Lappi and Bailey 1987; Sterba 2008) to obtain reliable results for the FSI (or information about the level of structural diversity. A table containing the different forest types and their corresponding number of inventory plots is provided in the Additional file 5.

Some previously developed indices of structural diversity used individual weightings for variables (Parkes et al. 2003; Geburek et al. 2010). This can only be justified, if there is a clear rationale for valuing some variables more or less than others, i.e. if it was known that a certain aspect of structural diversity had a proportionally higher or lower influence on species richness or diversity. In our study, there were no obvious variables that should receive more or less weight than others in order to represent the overall forests biodiversity. Weighting of variables could be performed when the FSI is linked to individual taxonomic groups, because some elements of structural diversity that are crucial for one taxonomic group could lead to an absence of other taxonomic groups (Økland 1996). In addition, we tested the performance of the FSI using random weightings applied to the selected variables. The results of the sensitivity analysis, which used random weightings between 0 and 2 for each variable, show that the performance of the FSI was insensitive to weightings of variables $\left(R^{2}=0.97, \mathrm{CV}=0.01\right)$, which were therefore not applied in routine calculations (Fig. 2). 
Table 3 Core variables used in the Forest Structure Index and their recognized importance for biodiversity of forests

\begin{tabular}{llll}
\hline Variable & Aspect & Author & Explanation \\
\hline $\begin{array}{l}\text { DBHq (quadratic mean diameter } \\
\text { of trees } \geq 7 \mathrm{~cm} \text { at breast height) }\end{array}$ & GS growing stock & Spies and Franklin (1991); Uuttera et al. & Common variable to describe stand \\
& & (1997); Acker et al. (1998); Ferreira and & $\begin{array}{l}\text { structure; higher DBHq implies older } \\
\text { and taller stands with high biomass, } \\
\text { typical forest microclimate, and more } \\
\text { presence of habitat attributes of mature } \\
\text { forests }\end{array}$ \\
& & Prance (1999); Ziegler (2000); & Tanabe et al. (2001)
\end{tabular}

DBH sd (standard deviation of diameter UA uneven-agedness at breast height of trees $\geq 7 \mathrm{~cm}$ )
Acker et al. (1998); Neumann and Starlinger (2001); McElhinny et al. (2006)
Height sd (standard deviation of mean height of trees $\geq 7 \mathrm{~cm} \mathrm{DBH}$ )

Bark (index to describe diversity of bark types)
$\mathrm{VH}$ vertical-heterogeneity

MacArthur and MacArthur (1961); Sabatini et al. (2015); McElhinny et al. (2006)

BD bark diversity

Gilmore (1985): Dickman (1991): Pearce (1996); Eyre and Smith (1997); McElhinny et al. (2006); Bhadra et al. (2008)

High standard deviation of DBH implies a diverse stand structure with patches of different densities and tree dimensions; many niches are provided for different taxa; relates to canopy layering

Standard deviation of stand height describes the vertical heterogeneity of stands directly; relates to canopy layering

Diversity of bark types (smooth, fissured, peeling, scaly, cracked, etc.) in forest stands implies a variety of habitats for many species to be found there (insects, fungi, yeasts, spiders, epiphytes). Tree diameter and bark-development phases are considered

Flower-diversity (diversity of fruiting and flowering trees)

VolTrees40 (volume per hectare of trees with a $\mathrm{DBH} \geq 40 \mathrm{~cm}$ )

N DC (number of decay classes)

Deadwood st mean DBH (mean DBH of standing deadwood)

Deadwood d average mean diameter (average mean diameter of downed deadwood)

SR (richness of tree species with $\mathrm{DBH} \geq 7 \mathrm{~cm})$

SR Reg (species richness of regeneration $(\mathrm{DBH}<7 \mathrm{~cm})$ )
FD Flower diversity

LLT Large living trees

Kavanagh (1987); Andrews et al. (1994); Smith et al. (1994); Soderquist and MacNally (2000); Herrera et al. (2001); Singh and Kushwaha (2005)

Spies and Franklin (1991); Tyrrell and Crow (1994); Koop et al. (1995); Acker et al. (1998); Van Den Meersschaut and Vandekerkhove (2000); Ziegler (2000); Larrieu and Cabanettes (2012)

DW DC deadwood decay Lassauce et al. (2011); Blaser et al. classes

(2013); Lachat et al. (2013);

Dittrich et al. (2014)

DW s standing deadwood

Drapeau et al. (2009); Rondeux and Sanchez (2010); Lassauce et al. (2011); Verkerk et al. (2011); Lachat et al. (2013)
DW d downed deadwood

$\mathrm{CH}$ compositional heterogeneity

REG regeneration
Drapeau et al. (2009); Rondeux and Sanchez (2010); Brin et al. (2011); Lassauce et al. (2011); Verkerk et al. (2011); Lachat et al. (2013); Kappes and Topp (2004)

Lähde et al. (1994); Maltamo (1997); Uuttera et al. (1997); Tilman (1999); Van Den Meersschaut and Vandekerkhove (2000); Uuttera et al. (2000); Sullivan et al. (2001); Pretzsch (2003); Pretzsch (2005)

Mosimann et al. (1987); Du Bus de Warnaffe and Deconchat (2008); Müller et al. (2008)
Food source for nectarivorous and frugivorous species (mainly insects, bats and birds)

Large trees have a special function as habitat or source of food for many taxa; they have a greater probability to provide microhabitat structures such as hollows, crown dead wood, etc.

Important for many taxonomic groups; many decay classes indicate a continuous recruitment of deadwood indicator for natural forest conditions

Important structural element for many taxa of xylobiotic species (habitat and

food source); more suitable than volume/ha because of strong extrapolation effects when sampled on small plots; stumps are excluded from the calculation

Important structural element for many taxa of xylobiotic species (habitat, food source, regeneration niche); surrogate for deadwood types and N/ha of dead wood pieces, justified by level of correlation and better distribution

Species richness of trees with $\mathrm{DBH} \geq$ $7 \mathrm{~cm}$ is important for diversity of dependent species, in particular hostspecific herbivores, detritivores, symbionts and pathogens

Important for many taxa like insects, mammals and birds; high SR Reg leads to more diverse future stand conditions
The small number of plots with very high and very low FSI-values indicate that the developed index is potentially sensitive to the existing level of diversity of structural elements in forests of SW-Germany, which include a broad range of structural diversities (from intensively managed forests to strict reserves). In contrast, one-sided 


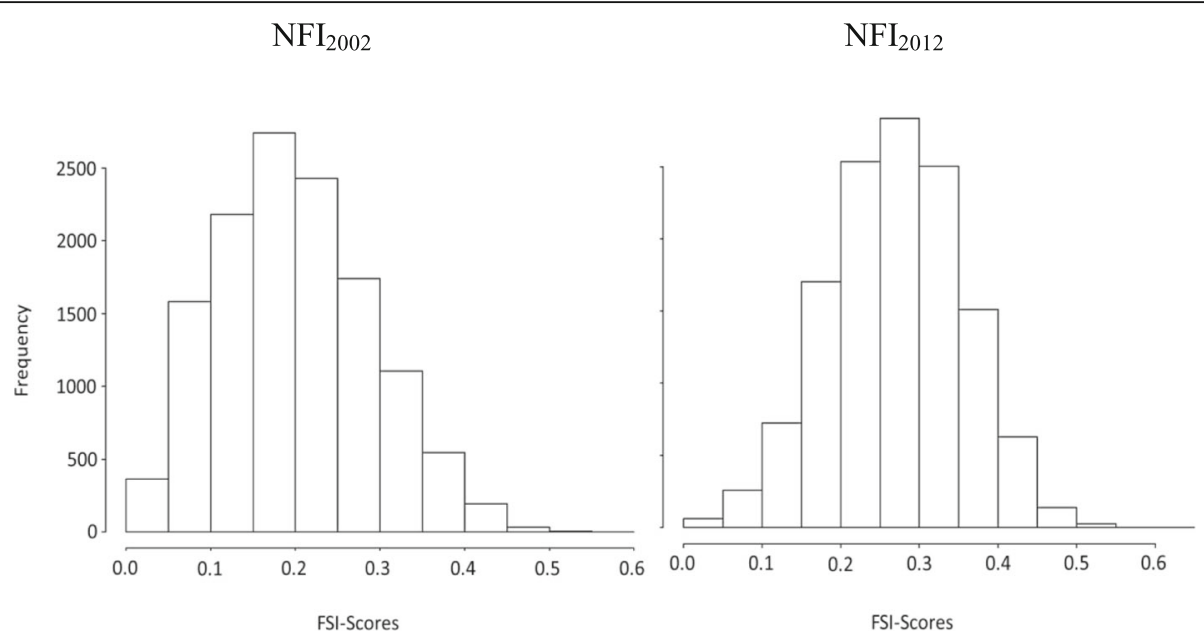

Fig. 2 Frequency distribution of scores of the forest structural diversity index $(F S I)$ for the second $\left(\mathrm{NFI}_{2002}\right)($ left, mean $=0.18)$ and third $\left(N F I_{2012}\right)$ national forest inventory (right, mean $=0.21$ ). Scores were calculated for 12.918 inventory plots within Baden-Württemberg. Differences between $\mathrm{NFI}_{2002}$ and $\mathrm{NFI}_{2012}$ are significant for an applied confidence level of 0.95

distributions for this diverse data-set would indicate that the FSI produces similar values for many sampling plots and was not sensitive enough to describe the diverse spectrum of structural diversity in forests. The histograms show a close to normal distribution and a broad range of FSI-scores, which represent different structural 'qualities' (from structurally poor to comparatively high levels of structural diversity (Fig. 2). A maximum FSI-score of 1 is theoretically possible but very unrealistic in reality, because all applied variables must be present at their maximum expression. In addition, high scores for some variables might exclude high scores for other variables (e.g. high species richness (mixture of shade-tolerant and shade-intolerant species) might exclude high species richness in the regeneration layer, caused by missing shade-intolerant species). The highest FSI-score calculated on the basis of $\mathrm{NFI}_{2002}$-data was 0.52 , which represents the highest level of structural diversity in forest-plots of Baden-Württemberg. The lowest FSI-scores were found in young stand development phases and the highest FSI-scores are found in old broadleaf-dominated stands which are conform to general assumptions on the level of structural diversity in different stand development phases of managed forests (e.g. Bazzaz 1975; Spies and Franklin 1991; Scherzinger 1996). Distributions of the FSI scores for other categories of forests (e.g. broadleaf/coniferous-dominated, beech-, oak-, pine-, spruce-dominated, three stand development phases, ownerships or number of canopy layers) are provided in the Additional file 6.

A comparison of FSI scores for the $\mathrm{NFI}_{2002}$ and $\mathrm{NFI}_{2012}$ showed that the index is sensitive to temporal changes in forest structure and composition and that the scores increased for all individual variables contributing to the index, except standing deadwood decreased slightly (Fig. 3).
The changes in the FSI for NFI data from Baden-Württemberg corresponded to results of the analysis of NFI-data for single variables (Fig. 3). These showed a small general increase in all structural elements apart from standing deadwood for the period between $\mathrm{NFI}_{2002}$ and $\mathrm{NFI}_{2012}$. In general, young stands had a lower structural diversity than middle-aged stands (Stand development phase 1 - FSI $\mathrm{NFI}_{2012}=0.14$; Stand development phase $2-$ FSI NFI $2012=$ 0.21). Not surprisingly, the FSI score for $\mathrm{NFI}_{2012}$ indicated that one-layered stands (0.14) were less diverse than two- $(0.21)$ or multi-layered stands $(0.24)$. The highest level of structural diversity was observed in old stands (0.28), followed by multi-layered stands (0.24). For all analysed forest types, except for young and young-coniferous dominated stands, an increase of structural diversity took place for the period $\mathrm{NFI}_{2002}-\mathrm{NFI}_{2012}$. The highest

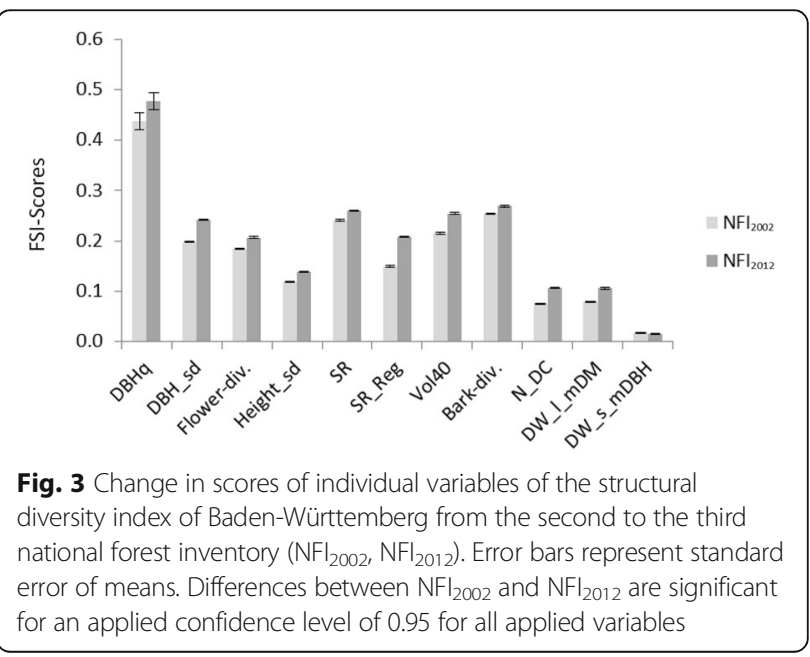


increase in structural diversity was found for stand development phase 2 and pine-dominated stands (0.04) (Additional file 7 and Fig. 4).

\section{Assessment of absolute FSI-scores}

Expressing the level of structural diversity in a single number may yield questionable results, especially if several, quite different aspects of structure are combined in one index (Whitman and Hagan 2007). For example, a deadwood-rich but species-poor stand can receive the same index-score as a stand without deadwood but a more diverse diameter distribution or species richness. However, this 'hidden information' of the FSI score can be made visible by depicting the changes in single FSI-variables (Fig. 3). This variation in structural attributes behind similar FSI-values is an inevitable
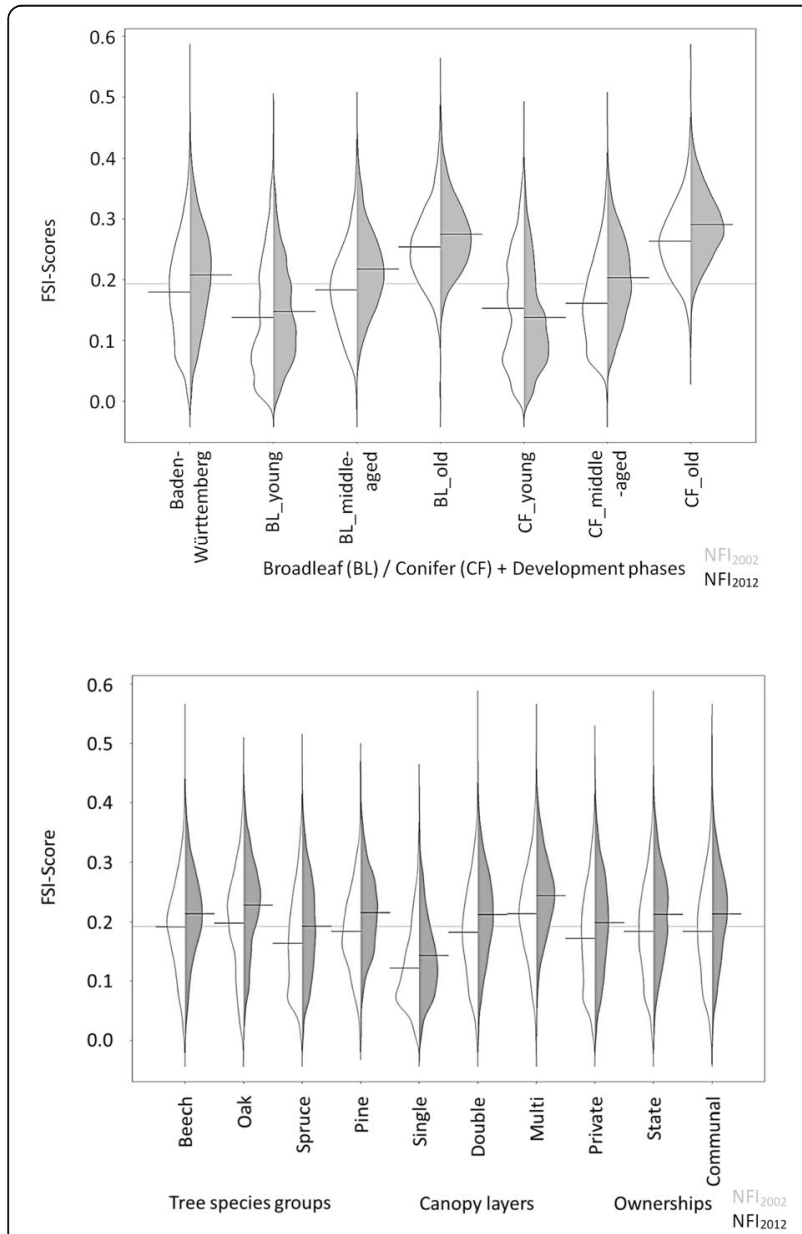

Fig. 4 Beanplots of FSI distributions in different forest types - left half of beans represents $\mathrm{NFI}_{2002}$ and the right half of beans represents $\mathrm{NFI}_{2012}$; direct comparison of $\mathrm{FSI}$ for $\mathrm{NF}_{2002}$ and $\mathrm{NFI}_{2012}$ per stand type as well as a comparison between different forest types; black lines indicate mean values of forest types; except of young coniferdominated stands, all types of forests show an increase between the FSI-score for $\mathrm{NFI}_{2002}$ and $\mathrm{NFI}_{2012}$. All types of forests show significant differences between the two NFIs (t-test, confidence level of 0.95) consequence of aggregation, but it is not per se unrealistic, because biodiversity is depending on many different structural aspects. If we assume that the different types and combinations of structural variables represent habitats for different taxa, then we can also expect quite different forest communities for similar FSI-scores.

In general, the FSI-score provides a standardised and transparent assessment of the overall diversity of large forest types. The highest FSI-score was found in old stands. In this type of forest, all variables included in the FSI, except for 'quadratic mean diameter at breast height,' standard deviation of diameter at breast height,' 'occurrence of large living trees' and 'Bark-diversity' assume approximately average values for forests in Baden-Württemberg. However, old stands scored significantly higher than the average for the above mentioned four variables, providing the underlying causes for the high overall FSI values in this forest type.

The adaption of NFIs to support biodiversity monitoring has developed over the last decades and is now more widely used. Additional variables for further information on deadwood or habitat trees, which are important to gain a comprehensive view on biodiversity in forests, have been included in the list of inventoried variables (Corona et al. 2011). Adaptations of threshold-values (for example changes in minimum sampled diameter of deadwood or threshold-diameter for large trees, which is used as a surrogate for habitat-trees) are easily possible in the FSI. This makes the FSI a flexible tool which can be adapted easily to inventory data from other types of forest ecosystems or other regions. In addition, variables that have not been sampled in past NFIs (of Germany) but provide information about further aspects of structural diversity can be included in the index, when data become available (e.g. information about the litter layer or microhabitats, Table 2). This important information could be obtained in upcoming NFIs to further support biodiversity monitoring in a more comprehensive way and thereby improve the information value of the FSI.

A comparison between the performance of FSI and other indices describing structural diversity of forests based on inventory data (e.g. Newsome and Catling 1979; Denslow and Guzman 2000; Parkes et al. 2003) was not possible in this study, because some variables required by these indices were not sampled in the NFI (e.g. 'canopy cover' or information about 'litter'). These other indices of stand structural diversity use variables that are not measured in most conventional forest inventories (e.g. litter decomposition, litter dry weight and thickness, number of hollow trees, amount of crown deadwood, swelling of trunk bases, species richness of small plants (shrubs or ground vegetation)), which would need to be collected in separate inventories that can be typically carried out only in specific forest types or regions. In contrast, the FSI presented here can be readily adapted to 
most other European large-scale National Forest Inventories, easily (e.g. Austria, Switzerland, Italy or Spain) because it uses variables that are measured in most European NFIs (Tomppo et al. 2010). In addition, it is possible to reduce the number of applied variables in the FSI (if some information is missing) because the aggregated score is calculated in a simple additive way and results are expressed in a relative instead of absolute numbers. However, the comparability of the FSI and its constituent variables with other inventories depends also on the sampling methods employed in the inventories.

\section{Angle count sampling and transfer of our approach to different inventory methods}

When using inventory data for a structural diversity index like the NFI of Germany, which is partly based on sampling via the angle count method, it is important to aggregate index-scores at a stratum level (e.g. forest-type) (Bitterlich 1952; Lappi and Bailey 1987; Sterba 2008). Observations or changes of structural diversity for single inventory plots should not be considered because dramatic changes recorded at individual plots may be caused by the sampling design rather than by actual changes in forest structure. Observed differences in variables between two inventories at a single plot may be attributable to the method of PPS (probability proportional to size) sampling, that angle count sampling is based on. Whether a tree is included in the sample or not depends on its diameter at breast height and its distance to the centre of the inventory plot. The associated low number of trees leads, in most cases, to a loss of information at the plot-level (justified by the need to optimize the sampling effort). For larger study areas and inventory strata, the accuracy of observations from angle count sampling is as high as that from inventories employing fixed radius circles (Lappi and Bailey 1987; Sterba 2008). On this basis, accurate calculations of harvested timber volume or biomass, growing stock, availability of certain products, etc. have been successfully performed in the past (Polley 2005; Kändler and Cullmann 2014; Polley and Kroiher 2017).

The low scores of deadwood-related variables of the FSI for Baden-Württemberg (deadwood standing, deadwood downed and deadwood decay classes, see Fig. 3) may be explained through the sampling of this attribute, which has a rare occurrence, on relatively small plots of $5 \mathrm{~m}$ radius (Meyer 1999; Ritter and Saborowski 2012). However, large amounts of deadwood, when scaled up to a hectare, can be recorded at individual plots (for example the highest value of downed deadwood $\left(1713 \mathrm{~m}^{3} \cdot \mathrm{ha}^{-1}\right)$ was the result of only two large trees sampled within the $5 \mathrm{~m}$ plot). Therefore, average mean diameter was chosen for downed deadwood, mean DBH for standing deadwood and number of decay classes for the aspect of decay classes. These variables did not have to be scaled up to hectare values and therefore delivered more accurate values than volume $\cdot \mathrm{ha}^{-1}$ or number.ha ${ }^{-1}$. This problem (rare occurrence) may be exacerbated by the high threshold value for deadwood in $\mathrm{NFI}_{2002}$ (20 $\mathrm{cm}$ diameter at the large end). In addition, in most forest areas deadwood occurs in a clumped distribution. Hence single 5-m-radius plots are not sufficiently large to quantify dead wood representatively for entire stands (Ritter and Saborowski 2012). While this variability can normally be dealt with through aggregation of inventory plots to the level of sufficiently large strata to derive representative mean values (e.g. Lombardi et al. 2015), it leads to very high deviation of deadwood volumes determined at the plot level from the mean of the stratum, if dead wood volumes determined in one such plot are scaled directly to the hectare level. Similarly, the occurrence of other rare elements (like hollow trees, very large trees or rare tree species) is probably underestimated when compared to other inventory methods using larger fixed sampling plots.

A transfer of the approach presented here to inventories using fixed radius circles, as they are used in other types of inventories appears to be possible, but further research has to be done on this topic, e.g. if an adaption of threshold-values for the applied variables is needed.

\section{Conclusion}

The main goal of this study was to assess the feasibility of an index of forest structural diversity based on large-scale forest inventory data to support biodiversity monitoring. Our results show that the index developed here provides an objective assessment of the status of structural diversity for different forest types and that it is sensitive to temporal changes. More detailed information about the level of structural diversity (single variables or their development over time) in different forest types can be derived. Our index of forest structural diversity can be readily adapted to other, similar types of national or regional forest inventories. The index of forest structural diversity developed here serves one of the major directions in recent developments of forest inventories towards multipurpose resources surveys, namely the incorporation of additional variables that are not directly related to traditional inventory purposes such as assessment of timber, wood volume increments or carbon stocks and sequestration (Corona 2016). However, the index has been derived from variables that are already measured in current forest inventories and hence it can be easily calculated without much extra cost. It can provide an evidence basis to support societal debates and decision making processes about biodiversity conservation in forests at large-scale. The expression of structural 
diversity in a single number allows a direct comparison among different types of forest stands and it facilitates the depiction of changes within single types of forests over time. These are considered important aspects of the reporting on sustainability of forests in a general way. A more specific assessment of individual structural elements used in the index can be easily derived, if the focus is on monitoring particular aspects of structural diversity (e.g. the presence of large living trees or the number of tree species), for example to guide forest management and planning.

\section{Additional files}

Additional file 1: Sampling design of NFI in Germany; Elements and methods of data sampling applied in NFI2002 and NFI2012 of Germany; *: sampling of deadwood pieces with a diameter of $20 \mathrm{~cm}$ in NFI2002 was reduced to $10 \mathrm{~cm}$ in NFI2012; further information can be found at https://www.bundeswaldinventur.de. (PDF $137 \mathrm{~kb}$ )

Additional file 2: Transformation of variables into scores (between 0 and 1) based on variable-values of NFI2002 and literature; '-': threshold values from literature not available or (needed). (PDF $61 \mathrm{~kb}$ )

Additional file 3: Comprehensive list of variables derived from NFI2002 and NFI2012; $N=52$. (PDF $230 \mathrm{~kb}$ )

Additional file 4: Variables, aspects of structural diversity and correlations with other calculated variables of the comprehensive list of structural attributes, derived from NFI2002 data for whole BadenWürttemberg (forest type 'BW'). (PDF $230 \mathrm{~kb}$ )

Additional file 5: Analysed forest types and corresponding number of sampled plots, distributed over Baden-Württemberg, Germany: (PDF 145 kb)

Additional file 6: FSI-distribution for a selection of different forest types of Baden-Württemberg for NFI2002 and NFI2012 (y-axis: frequency of sampling plots; $x$-axis: FSI-score). (PDF $214 \mathrm{~kb})$

Additional file 7: Overview of analysed forest types and FSI-scores for NFI2002 and NFI2012. (PDF $143 \mathrm{~kb}$ )

\section{Abbreviations \\ BW: State of Baden-WürttembergSW-Germany; Cor: Level of correlation (pearson); CV: Coefficient of variation; DBH: Diameter at breast height $(130 \mathrm{~cm}) ;$ FSI: Forest structure index; $\mathrm{m}^{3} \cdot \mathrm{ha}^{-1}$ : Cubic metre per hectare; $\mathrm{N}$ : Number; NFI: National forest inventory; PCA: Principal component analysis; $R^{2}$ : Coefficient of determination; $X_{\min /} X_{\max }$ : Minimum/Maximum of variable- values applied to calculate the FSI}

\section{Acknowledgements}

We like to thank Dr. Gerald Kändler (Forest Research Institute of BadenWürttemberg, Dep. of Biometry and Informatics) for supporting the analyses of NFI data. Also special thanks to Joachim Maack for support with statistical analysis.

\section{Funding}

This work was supported by a grant from the Ministry of Science, Research and the Arts of Baden-Württemberg (7533-10-5-78) to Jürgen Bauhus. Felix Storch received additional support through the BBW ForWerts Graduate Program.

\section{Availability of data and materials}

The datasets that form the basis of all analyses in our study are free available at https://bwi.info/Download/de/BWI-Basisdaten/ACCESS2003/.

The datasets supporting the conclusions of this article are included in the additional files (Additional files 1, 2, 3, 4, 5, 6 and 7).

\section{Authors' contributions}

FS planned and conducted the study including data management and analysis and wrote the majority of the manuscript; CFD provided support in statistical methods and analysis and contributed to the manuscript; JB conceived and guided the study and co-wrote the manuscript. All authors read and approved the final manuscript.

Ethics approval and consent to participate

Not applicable.

\section{Consent for publication}

Not applicable.

\section{Competing interests}

The authors declare that they have no competing interests.

\section{Author details}

${ }^{1}$ Chair of Silviculture, Tennenbacherstr. 4, University of Freiburg, D-79085 Freiburg, Germany. ${ }^{2}$ Chair of Biometry, Tennenbacherstr. 4, University of Freiburg, D-79085 Freiburg, Germany.

Received: 29 May 2018 Accepted: 20 August 2018

Published online: 12 September 2018

\section{References}

Abrahamsson M, Lindbladh M (2006) A comparison of saproxylic beetle occurrence between man-made high- and low-stumps of spruce (Picea abies). Forest Ecol Manag 226(1-3):230-237. https:/doi.org/10.1016/j.foreco.2006.01.046

Acker SA, Sabin TE, Ganio LM, McKee WA (1998) Development of old-growth structure and timber volume growth trends in maturing Douglas-fir stands. Forest Ecol Manag 104(1-3):265-280. https://doi.org/10.1016/S0378-1127(97)00249-1

Andrews SP, Gration G, Quin D, Smith AP (1994) Description and assessment of forestry impacts on fauna of the Urbenville forestry management area. Report for State Forests of New South Wales Austeco Environmental Consultants, Armidale

Bachofen H, Zingg A (2001) Effectiveness of structure improvement thinning on stand structure in subalpine Norway spruce (Picea abies (L.) karst.) stands. Forest Ecol Manag 145(1-2):137-149. https://doi.org/10.1016/S0378-1127(00)00581-8

Barbier S, Chevalier R, Loussot P, Bergès L, Gosselin F (2009) Improving biodiversity indicators of sustainable forest management. Tree genus abundance rather than tree genus richness and dominance for understory vegetation in French lowland oak hornbeam forests. Forest Ecol Manag 258: 176-186. https://doi.org/10.1016/j.foreco.2009.09.004

Barbier S, Gosselin F, Balandier P (2008) Influence of tree species on understory vegetation diversity and mechanisms involved - a critical review for temperate and boreal forests. Forest Ecol Manag 254(1):1-15. https://doi.org/10.1016/j.foreco.2007.09.038

Barnett JL, How RA, Humphreys WF (1978) The use of habitat components by small mammals in eastern Australia. Austral Ecol 3(3):277-285. https://doi.org/10.1111/j.1442-9993.1978.tb01177.x

Bauhus J, Puettmann K, Messier C (2009) Silviculture for old-growth attributes. Forest Ecol Manag 258(4):525-537. https://doi.org/10.1016/j.foreco.2009.01.053

Bauhus J, Puettmann KJ, Kuehne C (2013) Close-to-nature forest management in Europe: does it support complexity and adaptability of forest ecosystems? In: Messier C, Puettmann KJ, Coates KD (eds) Managing forests as complex adaptive systems: building resilience to the challenge of global change. Routledge, the Earthscan forest library, pp 187-213

Bauhus J, Pyttel P (2015) Managed forests. In: Peh KSH, Corlett RT, Bergeron Y (eds) Routledge handbook of Forest ecology. Routledge, Oxon, pp 75-90

Bazzaz FA (1975) Plant species diversity in old-field successional ecosystems in southern Illinois. Ecology 56(2):485-488

Bhadra B, Rao RS, Singh PK, Sarkar PK, Shivaji S (2008) Yeasts and yeast-like fungi associated with tree bark: diversity and identification of yeasts producing extracellular endoxylanases. Curr Microbiol 56(5):489-494

Bitterlich W (1952) Die Winkelzählprobe. Forstwissenschaftliches Centralblatt, 71(7-8), 215-225.

Blaser S, Prati D, Senn-Irlet B, Fischer M (2013) Effects of forest management on the diversity of deadwood-inhabiting fungi in central European forests. Forest Ecol Manag 304:42-48. https://doi.org/10.1016/j.foreco.2013.04.043 
Bouget C, Larrieu L, Nusillard B, Parmain G (2013) In search of the best local habitat drivers for saproxylic beetle diversity in temperate deciduous forests. Biodivers Conserv 22(9):2111-2130

Boyden S, Binkley D, Shepperd W (2005) Spatial and temporal patterns in structure, regeneration, and mortality of an old-growth ponderosa pine forest in the Colorado front range. Forest Ecol Manag 219(1):43-55. https://doi.org/10.1016/j.foreco.2005.08.041

Brin A, Bouget C, Brustel H, Jactel H (2011) Diameter of downed woody debris does matter for saproxylic beetle assemblages in temperate oak and pine forests. J Insect Conserv 15(5):653-669. https://doi.org/10.1007/s10841-010-9364-5

Brunialti G, Frati L, Aleffi M, Marignani M, Rosati L, Burrascano S, Ravera S (2010) Lichens and bryophytes as indicators of old-growth features in Mediterranean forests. Plant Biosyst 144(1):221-233. https://doi.org/10.1080/11263500903560959

Burgman MA, Breininger DR, Duncan BW, Ferson S (2001) Setting reliability bounds on habitat suitability indices. Ecol Appl 11(1):70-78

Burrascano S, Keeton WS, Sabatini FM, Blasi C (2013) Commonality and variability in the structural attributes of moist temperate old-growth forests. A global review. Forest Ecol Manag 291:458-479. https:/doi.org/10.1016/j.foreco.2012.11.020

Burrascano S, Lombardi F, Marchetti M (2008) Old-growth forest structure and deadwood: are they indicators of plant species composition? A case study from Central Italy. Plant Biosyst 142(2):313-323. https://doi.org/10.1080/ 11263500802150613

Burrascano S, Sabatini FM, Blasi C (2011) Testing indicators of sustainable forest management on understorey composition and diversity in southern Italy through variation partitioning. Plant Ecol 212(5):829-841. https://doi.org/10. 1007/s11258-010-9866-y

Bütler R, Lachat T, Larrieu L, Paillet Y (2013) Habitat trees: key elements for forest biodiversity. In: Kraus D, Krumm F (eds) Integrative approaches as an opportunity for the conservation of forest biodiversity. European Forest Institute, Joensuu, pp 84-91

Castagneri D, Garbarino M, Berretti R, Motta R (2010) Site and stand effects on coarse woody debris in montane mixed forests of eastern Italian alps. Forest Ecol Manag 260(9):1592-1598. https://doi.org/10.1016/j.foreco.2010.08.008

Chirici G, Winter S, McRoberts RE (2011) National Forest Inventories. Springer Netherlands (managing Forest ecosystems, v.20), Dordrecht

Corona P (2016) Consolidating new paradigms in large-scale monitoring and assessment of forest ecosystems. Environ Res 144:8-14

Corona P, Chirici G, McRoberts RE, Winter S, Barbati A (2011) Contribution of largescale forest inventories to biodiversity assessment and monitoring. Forest Ecol Manag 262(11):2061-2069. https://doi.org/10.1016/j.foreco.2011.08.044

Corona P, Köhl M, Marchetti M (2003) Advances in forest inventory for sustainable forest management and biodiversity monitoring. Kluwer Academic Publishers, Dordrecht

Denslow JS, Guzman GS (2000) Variation in stand structure, light, and seedling abundance across a tropical moist forest chronosequence, Panama. J Veg Sci $11: 201-212$

Dickman CR (1991) Use of trees by ground-dwelling mammals: implications for management. In: Lunney D (ed) Conservation of Australia's forest fauna. Royal Zoological Society of New South Wales, Mosman NSW, pp 125-136

Dittrich S, Jacob M, Bade C, Leuschner C, Hauck M (2014) The significance of deadwood for total bryophyte, lichen, and vascular plant diversity in an oldgrowth spruce forest. Plant Ecol 215(10):1123-1137. https://doi.org/10.1007/ s11258-014-0371-6

Drapeau P, Nappi A, Imbeau L, Saint-Germain M (2009) Standing deadwood for keystone bird species in the eastern boreal forest: managing for snag dynamics. Forest Chron 85(2):227-234. https://doi.org/10.5558/tfc85227-2

Du Bus de Warnaffe G, Deconchat M (2008) Impact of four silvicultural systems on birds in the Belgian Ardenne: implications for biodiversity in plantation forests. Biodivers Conserv 17(5):1041-1055. https://doi.org/10.1007/s10531-008-9364-x

Duelli P, Obrist MK (2003) Biodiversity indicators: the choice of values and measures. Agric Ecosyst Environ 98(1-3):87-98. https://doi.org/10.1016/ S0167-8809(03)00072-0

Dueser RD, Shugart HH (1978) Microhabitats in a forest-floor small mammal Fauna. Ecology 59(1):89-98. https://doi.org/10.2307/1936634

Eyre TJ, Smith AP (1997) Floristic and structural habitat preferences of yellowbellied gliders (Petaurus australis) and selective logging impacts in Southeast Queensland, Australia. Forest Ecol Manag 98(3):281-295

Ferreira LV, Prance GT (1999) Ecosystem recovery in terra firme forests after cutting and burning: a comparison on species richness, floristic composition and forest structure in the Jaú National Park, Amazonia. Bot J Linn Soc 130(2):97-110. https://doi.org/10.1111/j.1095-8339.1999.tb00514.x
Gardner TA (2010) Monitoring Forest biodiversity. Improving conservation through ecologically responsible management. Routledge, London

Geburek T, Milasowszky N, Frank G, Konrad H, Schadauer K (2010) The Austrian forest biodiversity index: all in one. Ecol Indic 10(3):753-761. https://doi.org/ 10.1016/j.ecolind.2009.10.003

Gilmore AM (1985) The influence of vegetation structure on the density of insectivorous birds. In: Keast A, Recher HF, Ford HA, Saunders DA (eds) Birds of eucalypt forests and woodlands: ecology, conservation, management. Surrey Beatty \& Sons, Chipping Norton, pp 21-31

Gustafsson L, Baker SC, Bauhus J, Beese WJ, Brodie A, Kouki J, Lindenmayer DB, Lõhmus A, Martínez Pastur G, Messier C, Neyland M, Palik B, Sverdrup-Thygeson A, Volney WJA, Wayne A, Franklin JF (2012) Retention forestry to maintain multifunctional forests: a world perspective. Bioscience 62(7):633-645

Hao Z, Zhang J, Song B, Ye J, Li B (2007) Vertical structure and spatial associations of dominant tree species in an old-growth temperate forest. Forest Ecol Manag 252(1-3):1-11. https://doi.org/10.1016/j.foreco.2007.06.026

Hatanaka N, Wright W, Loyn RH, Mac Nally R (2011) 'Ecologically complex carbon'- linking biodiversity values, carbon storage and habitat structure in some austral temperate forests. Glob Ecol Biogeogr 20(2):260-271. https://doi.org/10.1111/j.1466-8238.2010.00591.x

Hello P (1985) Effects of forest regeneration on the structure of bird communities in northern Finland. Ecography 8(2):120-132. https://doi.org/10.1111/j.16000587.1985.tb01162.x

Herrera MGL, Hobson KA, Manzo AA, Estrada BD, Sánchez-Cordero V, Méndez CG (2001) The role of fruits and insects in the nutrition of frugivorous bats: evaluating the use of stable isotope models ${ }^{1}$. Biotropica 33(3):520-528. https://doi.org/10.1646/0006-3606(2001)033[0520:TROFAl]2.0.CO;2

Hoover CM, Leak WB, Keel BG (2012) Benchmark carbon stocks from old-growth forests in northern New England, USA. Forest Ecol Manag 266:108-114. https://doi.org/10.1016/j.foreco.2011.11.010

Hoppe B, Purahong W, Wubet T, Kahl T, Bauhus J, Arnstadt T (2016) Linking molecular deadwood-inhabiting fungal diversity and community dynamics to ecosystem functions and processes in central European forests. Fungal Divers 77(1):367-379. https://doi.org/10.1007/s13225-015-0341-x

Houghton RA (2005) Aboveground forest biomass and the global carbon balance. Glob Chang Biol 11(6):945-958. https://doi.org/10.1111/j.1365-2486. 2005.00955.x

Humphrey JW, Davey S, Peace AJ, Ferris R, Harding K (2002) Lichens and bryophyte communities of planted and semi-natural forests in Britain: the influence of site type, stand structure and deadwood. Biol Conserv 107(2): 165-180. https://doi.org/10.1016/S0006-3207(02)00057-5

Kändler G (2006) Abschlussbericht zum vorhaben "vertiefende analyse der BWI²-daten unter den aspekten naturnähe und biodiversität". (Kurzbezeichnung: BWI2 Biodiversitätsauswertung) Forschungsauftrag 04HS062 Gerald Kändler, Freiburg

Kändler G, Cullmann D (2014) Der wald in Baden-Württemberg. Ausgewählte Ergebnisse der dritten Bundeswaldinventur. Forstliche Versuchs- und Forschungsanstalt Baden-Württemberg (FVA), Freiburg

Kappes H, Topp W (2004) Emergence of Coleoptera from deadwood in a managed broadleaved forest in Central Europe. Biodivers Conserv 13:1905-1924

Kavanagh R (1987) Forest phenology and its effect on foraging behaviour and selection of habitat by the yellow-bellied glider, Petaurus-Australis Shaw. Wildlife Res 14(4):371-384

Keeton WS (2006) Managing for late-successional/old-growth characteristics in northern hardwood-conifer forests. Forest Ecol Manag 235(1-3):129-142. https://doi.org/10.1016/j.foreco.2006.08.005

Koop H, Rijksen HD, Wind J (1995) Tools to diagnose forest integrity; an appraisal method substantiated by silvi-star assessment of diversity and forest structure. CIFOR IUFRO symposium, Chiang Mai

Kuuluvainen T (2009) Forest management and biodiversity conservation based on natural ecosystem dynamics in northern Europe: the complexity challenge. Ambio 38(6):309-315. https://doi.org/10.1579/08-A-490.1

Lachat T, Bouget C, Bütler R, Müller J (2013) Totholz: Quantitative und qualitative Voraussetzungen für die Erhaltung der biologischen Vielfalt von Xylobionten. In: Kraus D, Krumm F (eds) Integrative Ansätze als Chance für die Erhaltung der Artenvielfalt in Wäldern. Rombach digitale manufaktur, Freiburg

Lähde E, Laiho O, Norokorpi Y, Saksa T (1994) Structure and yield of all-sized and even-sized conifer-dominated stands on fertile sites. Ann For Sci 51(2):97109. https://doi.org/10.1051/forest:19940201

Lappi J, Bailey RL (1987) Estimation of the diameter increment function or other tree relations using angle-count samples. For Sci 33(3):725-739 
Larrieu L, Cabanettes A (2012) Species, live status, and diameter are important tree features for diversity and abundance of tree microhabitats in subnatural montane beech-fir forests. Can J For Res 42(8):1433-1445

Larsson TB (2001) Biodiversity evaluation tools for European forests. In: Larsson TB (ed) Ecological Bulletins, vol 50. Wiley-Blackwell, New Jersey, p 240

Lassauce A, Paillet Y, Jactel H, Bouget C (2011) Deadwood as a surrogate for forest biodiversity: meta-analysis of correlations between deadwood volume and species richness of saproxylic organisms. Ecol Indic 11(5):1027-1039. https://doi.org/10.1016/j.ecolind.2011.02.004

Lindenmayer DB, Franklin JF (2002) Conserving forest biodiversity: a comprehensive multiscaled approach. Island Press, Washington DC

Lindenmayer DB, Margules CR, Botkin DB (2000) Indicators of biodiversity for ecologically sustainable forest management. Conserv Biol 14(4):941-950. https://doi.org/10.1046/j.1523-1739.2000.98533.x

Lombardi F, Cocozza C, Lasserre B, Tognetti R, Marchetti M (2011) Dendrochronological assessment of the time since death of dead wood in an old growth Magellan's beech forest, Navarino Island (Chile). Austral Ecol 36(3):329-340. https://doi.org/10.1111/j.1442-9993.2010.02154.x

Lombardi F, Marchetti M, Corona P, Merlini P, Chirici G, Tognetti R, Burrascano S, Alivernini A, Puletti N (2015) Quantifying the effect of sampling plot size on the estimation of structural indicators in old-growth forest stands. Forest Ecol Manag 346:89-97

MacArthur RH, MacArthur JW (1961) On bird species diversity. Ecology 42: 594-598

MacFarlane DW, Luo A (2009) Quantifying tree and forest bark structure with a barkfissure index. Can J For Res 39(10):1859-1870. https://doi.org/10.1139/X09-098

Maltamo M (1997) Comparing basal area diameter distributions estimated by tree species and for the entire growing stock in a mixed stand. Silva Fenn 31(1):53-65

Margules CR, Pressey RL, Williams PH (2002) Representing biodiversity: data and procedures for identifying priority areas for conservation. J Biosci 27(4):309-326. https://doi.org/10.1007/BF02704962

McElhinny C, Gibbons P, Brack C (2006) An objective and quantitative methodology for constructing an index of stand structural complexity. Forest Ecol Manag 235(1-3):54-71. https://doi.org/10.1016/j.foreco.2006.07.024

Meyer P (1999) Totholzuntersuchungen in nordwestdeutschen Naturwäldern: Methodik und erste Ergebnisse. Forstwiss Centralbl 118(1-6):167-180. https://doi.org/10.1007/BF02768985

Michel AK, Winter S, Linde A (2011) The effect of tree dimension on the diversity of bark microhabitat structures and bark use in Douglas-fir (Pseudotsuga menziesii var. menziesii ). Can J For Res 41(2):300-308. https://doi.org/10.1139/X10-207

Mosimann P, Naef-Daenzer B, Blattner M (1987) Die zusammensetzung der avifauna in typischen waldgesellschaften der Schweiz. Der Ornithologische Beobachter 84:275-299

Müller J, Bußler H, Kneib T (2008) Saproxylic beetle assemblages related to silvicultural management intensity and stand structures in a beech forest in southern Germany. J Insect Conserv 12(2):107-124. https://doi.org/10.1007/ s10841-006-9065-2

Neumann M, Starlinger F (2001) The significance of different indices for stand structure and diversity in forests. Forest Ecol Manag 145(1-2):91-106. https://doi.org/10.1016/S0378-1127(00)00577-6

Newsome AE, Catling PC (1979) Habitat preferences of mammals inhibiting heathlands of warm temperate coastal, montane and alpine regions of southeastern Australia. In: Specht RL (ed) Ecosystems of the world, vol 9A. Elsevier, Amsterdam, pp 301-316

Niemeijer D, de Groot RS (2008) Framing environmental indicators: moving from causal chains to causal networks. Environ Dev Sustain 10(1):89-106

Nilsson SG, Niklasson M, Hedin J, Aronsson G, Gutowski JM, Linder P (2002) Densities of large living and dead trees in old-growth temperate and boreal forests. Forest Ecol Manag 161(1-3):189-204. https://doi.org/10.1016/S03781127(01)00480-7

Norris C, Hobson P, Ibisch PL (2012) Microclimate and vegetation function as indicators of forest thermodynamic efficiency. J Appl Ecol 49:562-570. https://doi.org/10.1111/j.1365-2664.2011.02084.x

Noss RF (1990) Indicators for monitoring biodiversity: a hierarchical approach. Conserv Biol 4(4):355-364. https://doi.org/10.1111/j.1523-1739.1990.tb00309.x

OECD (2003) OECD environmental indicators: development, measurement and use. Reference paper, Paris, p 50

Økland B (1996) Unlogged forests: important sites for preserving the diversity of mycetophilids (Diptera: Sciaroidea). Biol Conserv 76(3):297-310

Parkes D, Newell G, Cheal D (2003) Assessing the quality of native vegetation: the 'habitat hectares' approach. Ecol Manag Restor 4(suppl 1):29-38
Pearce J (1996) Habitat selection by the white-eared honeyeater. II. A case study at Yellingbo state nature reserve, south-East Victoria. Emu-Austral Ornithology 96(1):50-54

Persiani AM, Audisio P, Lunghini D, Maggi O, Granito VM, Biscaccianti AB, Chiavetta U, Marchetti M (2010) Linking taxonomical and functional biodiversity of saproxylic fungi and beetles in broad-leaved forests in southern Italy with varying management histories. Plant Biosyst Int J Dealing Aspects Plant Biol 144(1):250-261. https://doi.org/10.1080/11263500903561114

Pielou EC (1975) Ecological diversity. Wiley, New York

Plieninger T, Bieling C, Gerdes H, Ohnesorge B, Schaich H, Schleyer C, Wolff F (2010) Ökosystemleistungen in Kulturlandschaften-Konzept und Anwendung am Beispiel der Biosphärenreservate Oberlausitz und Schwäbische Alb. Natur und Landschaft 85(5):187-192

Polley H (2005) Die zweite Bundeswaldinventur - BWI² - Der Inventurbericht. Bundesministerium für Ernährung. Landwirtschaft und Verbraucherschutz, Berlin

Polley H (2010) Monitoring in Wäldern: Die Bundeswaldinventur und Verknüpfungen für Naturschutzfragen. Naturschutz Biol Vielfalt 83:65-78

Polley H, Kroiher F (2017) Nadelwälder in Deutschland. Pro Wald, Magazin des Deutschen Forstvereins. Bonn, pp 4-7

Pretzsch H (1997) Analysis and modelling of spatial stand structures. Methodological considerations based on mixed beech-larch stands in Lower Saxony. Forest Ecol Manag 97:237-253

Pretzsch H (2003) Diversität und Produktivität von Wäldern. Allgemeine Forst-und Jagdzeitung 174:88-98

Pretzsch H (2005) Stand density and growth of Norway spruce (Picea abies (L.) karst.) and European beech (Fagus sylvatica L.): evidence from long-term experimental plots. Eur J Forest Res 124(3):193-205. https://doi.org/10.1007/s10342-005-0068-4

Raison RJ, Flinn DW, Brown AG, Raison RJ, Brown AG, Flinn DW (2001) Application of criteria and indicators to support sustainable forest management: some key issues. Criteria and indicators for sustainable forest management. Papers presented at a IUFRO/CIFOR/FAO conference 'Sustainable forest management: fostering stakeholder input to advance development of scientifically based indicators', Melbourne

Ranius T, Ekvall H, Jonsson M, Bostedt G (2005) Cost-efficiency of measures to increase the amount of coarse woody debris in managed Norway spruce forests. Forest Ecol Manag 206(1-3):119-133. https:/doi.org/10.1016/j.foreco.2004.10.061

Recher HF (1991) The conservation and management of eucalypt forest birds: resource requirements for nesting and foraging. In: Conservation of Australia's forest fauna. Royal Zoological Society of New South Wales, Mosman, pp 25-34

Ritter T, Saborowski J (2012) Point transect sampling of deadwood: a comparison with well-established sampling techniques for the estimation of volume and carbon storage in managed forests. Eur J Forest Res 131(6):1845-1856. https://doi.org/10.1007/s10342-012-0637-2

Rondeux J, Sanchez C (2010) Review of indicators and field methods for monitoring biodiversity within national forest inventories. Core variable: deadwood. Environ Monit Assess 164(1-4):617-630. https://doi.org/10.1007/ s10661-009-0917-6

Sabatini FM, Burrascano S, Lombardi F, Chirici G, Blasi C (2015) An index of structural complexity for Apennine beech forests. iForest 8(3):314-323. https://doi.org/10. 3832/ifor1160-008

Scherzinger W (1996) Naturschutz im Wald: Qualitätsziele einer dynamischen Waldentwicklung. Praktischer Naturschutz-Stuttgart (Verlag Eugen Ulmer) — 447 S, 51 Farbabb, 119 s/w-Abb, 36 Tab ISBN 3-8001-3356-3. Zoosyst Evol 74(1):149

Simpson EH (1949) Measurement of diversity. Nature 163:688

Singh KP, Kushwaha CP (2005) Diversity of flowering and fruiting phenology of trees in a tropical deciduous forest in India. Ann Bota-London 97(2):265-276

Smith AP, Andrews SP, Moore DM (1994) Terrestrial fauna of the Grafton and casino state forest management areas: description and assessment of forestry impacts northern region state forests of New South Wales. State Forests of New South Wales, Grafton

Soderquist TR, MacNally R (2000) The conservation value of Mesic gullies in dry forest landscapes: mammal populations in the box-ironbark ecosystem of southern Australia. Biol Conserv 93(3):281-291

Spies TA, Franklin JF (1991) The structure of natural young, mature, and oldgrowth Douglas-fir forests in Oregon and Washington. In: Leonard FR, Keith BA (eds) Wildlife and vegetation of unmanaged Douglas-fir forests general technical report PNW-GTR-285. Portland, Douglas-fir forests of Oregon and Washington (continued), pp 91-111.

Staudhammer CL, LeMay VM (2001) Introduction and evaluation of possible indices of stand structural diversity. Can J For Res 31(7):1105-1115. https://doi.org/10.1139/cjfr-31-7-1105 
Sterba H (2008) Diversity indices based on angle count sampling and their interrelationships when used in forest inventories. Forestry 81(5):587-597. https://doi.org/10.1093/forestry/cpn010

Sullivan TP, Sullivan DS, Lindgren PMF (2001) Stand structure and small mammals in young lodgepole pine forest: 10-year results after thinning. Ecol Appl 11(4):1151. https://doi.org/10.2307/3061019

Taboada Á, Tárrega R, Calvo L, Marcos E, Marcos JA, Salgado JM (2010) Plant and carabid beetle species diversity in relation to forest type and structural heterogeneity. Eur J Forest Res 129(1):31-45. https://doi.org/10.1007/s10342008-0245-3

Tanabe S, Toda MJ, Vinokurova AV (2001) Tree shape, forest structure and diversity of drosophilid community: comparison between boreal and temperate birch forests. Ecol Res 16(3):369-385. https://doi.org/10.1046/j. 1440-1703.2001.00402.x

Tilman D (1999) The ecological consequences of changes in boidiversity: a search for general principles. Ecology 80(5):1455-1474. https://doi.org/10. 1890/0012-9658(1999)080

Tomppo E, Gschwantner T, Lawrence M, McRoberts RE, Gabler K, Schadauer K, Cienciala E (2010) National forest inventories. Pathways for Common Reporting. European Science Foundation, 541-553.

Tyrrell LE, Crow TR (1994) Structural characteristics of old-growth hemlockhardwood forests in relation to age. Ecology 75(2):370-386. https://doi.org/ $10.2307 / 1939541$

Uuttera J, Maltamo M, Hotanen JP (1997) The structure of forest stands in virgin and managed peatlands. A comparison between Finnish and Russian Karelia. Forest Ecol Manag 96(1-2):125-138. https://doi.org/10.1016/S0378-1127(97)00035-2

Uuttera J, Tokola T, Maltamo M (2000) Differences in the structure of primary and managed forests in East Kalimantan, Indonesia. Forest Ecol Manag 129(1-3): 63-74. https://doi.org/10.1016/S0378-1127(99)00157-7

Van Den Meersschaut D, Vandekerkhove K (2000) Development of a stand-scale forest biodiversity index based on the state Forest inventory. In: Hansen M, Burk $T$ (eds) Integrated tools for natural resources inventories in the $21 \mathrm{st}$ century. Gen tech rep NC-212. St. Paul. Minnesota, Department of agriculture, Forest Service, north central Forest Experiment Station. pp 340-350

Verkerk PJ, Lindner M, Zanchi G, Zudin S (2011) Assessing impacts of intensified biomass removal on deadwood in European forests. Ecol Indic 11(1):27-35. https://doi.org/10.1016/j.ecolind.2009.04.004

Watson J, Freudenberger D, Paull D (2001) An assessment of the focal-species approach for conserving birds in variegated landscapes in southeastern Australia. Conserv Biol 15(5):1364-1373. https://doi.org/10.1111/j.1523-1739.2001.00166.x

Whitman AA, Hagan JM (2007) An index to identify late-successional forest in temperate and boreal zones. Forest Ecol Manag 246(2-3):144-154. https://doi.org/10.1016/j.foreco.2007.03.004

Winter S, Möller GC (2008) Microhabitats in lowland beech forests as monitoring tool for nature conservation. Forest Ecol Manag 255(3-4):1251-1261. https://doi.org/10.1016/j.foreco.2007.10.029

Woinarski JCZ, Recher HF, Majer JD (1997) Vertebrates of eucalypt formations. In: Williams JE, JCZ W (eds) . Eucalypt ecology: individuals to ecosystems. Northern Territory, pp 303-341

Ziegler SS (2000) A comparison of structural characteristics between old-growth and postfire second-growth hemlock-hardwood forests in Adirondack Park, New York, USA. Glob Ecol Biogeogr 9(5):373-389. https://doi.org/10.1046/j. 1365-2699.2000.00191.x

Zotti M, Persiani AM, Ambrosio E, Vizzini A, Venturella G, Donnini D (2013) Macrofungi as ecosystem resources: conservation versus exploitation. Plant Biosyst 147(1):219-225. https://doi.org/10.1080/11263504.2012.753133

\section{Submit your manuscript to a SpringerOpen ${ }^{\circ}$ journal and benefit from:}

- Convenient online submission

- Rigorous peer review

- Open access: articles freely available online

- High visibility within the field

Retaining the copyright to your article

Submit your next manuscript at $\boldsymbol{\nabla}$ springeropen.com 